\title{
Cyrene as a Bio-based Solvent for HATU Mediated Amide Coupling
}

Received 00th January 20xx Accepted 00th January $20 x x$ DOI: $10.1039 / x 0 x \times 00000 x$

www.rsc.org/

\author{
Kirsty L. Wilson, ${ }^{a}$ Jane Murray, ${ }^{b}$ Craig Jamieson $^{\mathrm{a}}$ and Allan J. B. Watson ${ }^{\mathrm{c} *}$
}

Amide bonds are one of the underpinning linkages in all living systems and are fundamental within drug discovery. Current methods towards their synthesis frequently rely on the use of dipolar aprotic solvents; however, due to increasingly stringent regulations and growing societal pressures, safe and more sustainable alternatives are highly sought after. Herein, we evaluate the application of the bio-based solvent Cyrene ${ }^{\mathrm{TM}}$ in the HATU mediated synthesis of amides and peptides. We found that Cyrene functioned as a competent replacement for DMF in the synthesis of a series of lead-like compounds and dipeptides (25 examples, 63-100\%).

\section{Introduction}

The amide functionality is ubiquitous throughout the natural world, forming the backbone of essential biomolecules (e.g. proteins) as well as many widely used materials (e.g. polyamides). ${ }^{1,2}$ Additionally, the amide moiety has profound importance to modern pharmaceutical development. This is clearly demonstrated throughout the chemical literature, where amide bond formation is consistently highlighted as the most frequently performed transformation in medicinal chemistry. ${ }^{3-5}$ Indeed, Brown's recent analysis of past and present synthetic methodologies within medicinal chemistry revealed that $50 \%$ of manuscripts surveyed (a representative data set of 125 papers taken from J. Med. Chem. in 2014) contained the transformation in the context of small molecule synthesis. The authors also note that the amide functionality occurs in $>50 \%$ of pharmaceutical drug discovery patents and journals (as calculated by the IBEX database). ${ }^{3}$ In addition to these significant statistics within small molecule drug design, the number of peptides being approved for therapeutic use is growing dramatically. Analysis of the peptide drug market carried out by Nuss revealed that, as of 2016, the number of peptides approved as drugs was 56 while a further 178 were involved in clinical trials (Phase I-III). ${ }^{6}$ As such, efficient methods towards their formation are highly sought after.

Typically, amides are formed by the direct condensation of carboxylic acids and amines, usually using an activator of some kind, which is attractive due to the high abundance of starting materials. Established methods employ coupling reagents such as $\mathrm{HATU}^{7}$ and $\mathrm{COMU}^{8}$ and commonly rely on the use of dipolar aprotic solvents, the continued use of which is of great

\footnotetext{
a. Department of Pure and Applied Chemistry, WestCHEM, University of Strathclyde, Thomas Graham Building, 295 Cathedral Street, Glasgow, G1 1XL, UK.

b. Merck KGaA ,Frankfurter Straße 250, 64293 Darmstadt, Germany.

c. EaStChem, School of Chemistry, University of St Andrews, North Haugh, St Andrews, KY16 9ST, UK.

+ Corresponding authoraw260@st-andrews.ac.uk

Electronic Supplementary Information (ESI) available: [details of any supplementary information available should be included here]. See DOI: $10.1039 / \times 0 x \times 00000 x$
}

concern due to the safety issues they pose. Exposure to solvents such as DMF and NMP is associated with reproductive toxicity and, as such, have been placed on the Registration, Evaluation, Authorisation and Restriction of Chemicals (REACH) list of substances of very high concern with NMP additionally recommended for inclusion on the REACH authorisation list. ${ }^{9,10}$

In this respect, solvent selection and more specifically the reduction in usage of dipolar aprotic solvents such as DMF and NMP has been designated a focal area by leading pharmaceutical companies and academic groups. ${ }^{11}$ As such, a number of tools and guides have been published to allow chemists to identify suitable alternatives and make changes to their reaction manifold to align with current environmental advisory guidelines. ${ }^{12-17}$ Despite these efforts and increasingly stringent regulations, the use of dipolar aprotic solvents is still widespread. ${ }^{18}$ This is due to the superior solubilising power of DMF and NMP, which is why they are commonly encountered in amide bond formation and, more specifically in the synthesis of peptides.

Efforts have been made towards highlighting direct solvent replacement strategies within amide bond formation. We have previously evaluated the use of selected alternative solvents within four benchmark amide bond forming reactions, demonstrating that $\mathrm{CH}_{2} \mathrm{Cl}_{2}$ and DMF could successfully be replaced by more benign solvents. ${ }^{19}$ More recently, a series of papers have been published detailing the replacement of dipolar aprotic solvents within solid phase peptide synthesis (SPPS). ${ }^{20-24}$ In addition to these important contributions, emerging micellar technology has also allowed for the formation of amide bonds in aqueous media. ${ }^{25}$

Figure 1. Physical properties of Cyrene and DMF


In addition to the safety aspects surrounding the use of conventional solvents, growing societal and political pressure towards the greening of chemical industries places emphasis on the reduction of petroleum based chemicals in favour of those derived from sustainable sources. ${ }^{26}$ To address this movement, many Green Chemistry initiatives within academia and industry are exploring solvents which can be obtained from biomass. ${ }^{27-35}$ Dihydrolevoglucosenone (Cyrene ${ }^{\mathrm{TM}}$, Figure 1 ), which can be accessed from cellulose in two steps, has been shown to possess similar physical properties to DMF and other dipolar aprotic solvents and is not currently associated with any harmful effects. ${ }^{34-40}$ Cyrene has previously demonstrated successful application in materials chemistry, ${ }^{41,42}$ in addition to synthetic organic transformations. ${ }^{43-45}$ Based on our interest in solvent replacement strategies, ${ }^{21,46-49}$ we are pleased to report the use of Cyrene as a bio-based solvent in amide bond formation.

\section{Results and discussion}

To investigate the capacity of Cyrene as a solvent in amide bond formation we selected $N$-[(dimethylamino)-1H-1,2,3-triazolo-[4,5b]pyridin- 1-ylmethylene]- $\mathrm{N}$-methyl- methanaminium hexafluorophosphate $N$-oxide (HATU) as the coupling reagent ${ }^{7}$ in the benchmark coupling of $p$-toluic acid $\mathbf{1 a}$ and aniline $\mathbf{2 a}$ (Table $\mathbf{1}$ ).

Table 1. Reaction Optimisation ${ }^{a}$

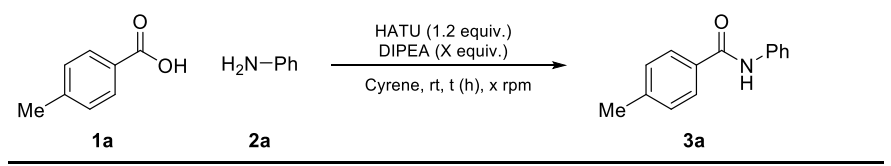

\begin{tabular}{|c|c|c|}
\hline Entry & Reaction conditions & $\begin{array}{c}\text { Conversion } \\
(\mu \pm \sigma \%)^{b}\end{array}$ \\
\hline
\end{tabular}

1

2

DIPEA (2 equiv.), $24 \mathrm{~h}^{c}$

$87 \pm 13$

DIPEA ( 2 equiv.), $1 \mathrm{~h}^{c}$

$84 \pm 21$

3

DIPEA (2 equiv.), 1 h, 200 rpm

$73 \pm 3$

4

DIPEA (2 equiv.), 1 h, 400 rpm

$71 \pm 3$

5

DIPEA (2 equiv.), 1 h, 800 rpm

$96 \pm 7$

6

DIPEA (3 equiv.), 1 h, 400 rpm

$92 \pm 2$

7

DIPEA ( 3 equiv.), 1 h, 400 rpm $^{d}$

$100 \pm 0$

${ }^{a} p$-Toluic acid (1 equiv., $0.25 \mathrm{mmol}$ ), aniline (1.1 equiv., $0.275 \mathrm{mmol}$ ), HATU (1.2 equiv., $0.3 \mathrm{mmol}$ ). ${ }^{b} \%$ conversion calculated by ${ }^{1} \mathrm{H}$ NMR using $1,4-$ dinitrobenzene as an internal standard. Presented as an average with standard deviation as a measure of consistency. $n=3 .{ }^{c}$ Variable stirring rate. ${ }^{d}$ DMF as solvent.

We found that the initial reaction proceeded smoothly allowing a reduced reaction time of $1 \mathrm{~h}$ (Entry 2). However, whilst high yields of $3 a$ were recorded further repetitions failed to deliver consistency. We found that this was due to variable stirring rate and as such, stringent control of this factor allowed us to establish consistency (Entry 3). Upon increasing the stirring rate higher yields with little variance could be achieved (Entry 3-5). Cyrene is a viscous liquid, which we believe gives rise to sub-optimal mixing at slow stirring rates. However, by increasing the stoichiometry of DIPEA we observed a decreased dependency of yield on stirring rate (Entry 6). Variation of coupling reagent and base failed to offer any improvement on conversion (see ESI).

We sought to investigate the utility of the optimized conditions (Table1, Entry 6) in the coupling of a range of carboxylic acids and amines (Scheme 1). Variation of the carboxylic acid and amine components was broadly successful (15 examples, 63-100\%) with alkyl (e.g., 3g, 3j) and aryl (e.g., 3k, 3m) moieties of both coupling partners tolerated. In addition to primary amines we found that both cyclic (e.g., 3c, 3i) and acyclic (e.g., 3f) secondary amines could be coupled in high yields. In the cases where comparatively lower yields were reported, such as $\mathbf{3 n}$, we found that the remaining mass balance was made up of unreacted activated ester.

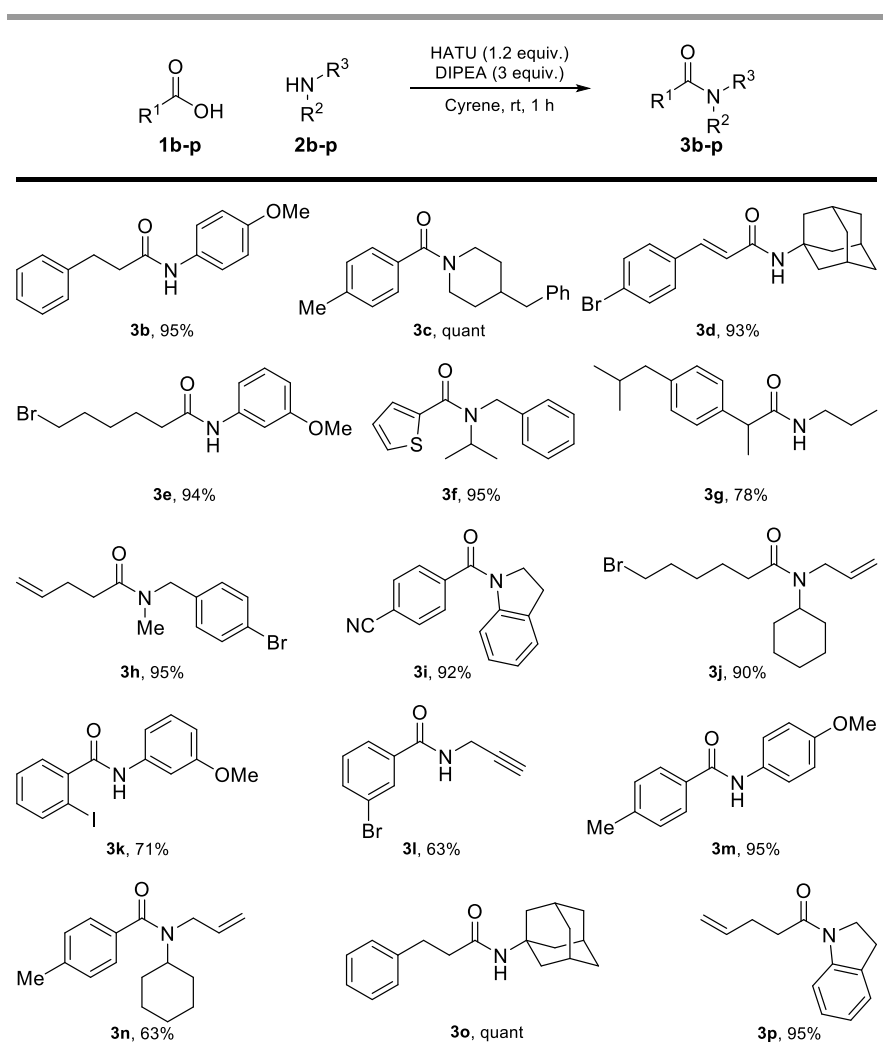

Scheme 1. HATU mediated amide bond formation: Scope of the transformation. Isolated yields. Acid (1 equiv., $0.25 \mathrm{mmol}$ ), amine (1.1 equiv., $0.275 \mathrm{mmol}$ ), HATU (1.2 equiv., $0.3 \mathrm{mmol}$ ), DIPEA (3 equiv., $0.75 \mathrm{mmol}$ ), Cyrene (1.25 mL, $0.2 \mathrm{M}), \mathrm{rt}, 1 \mathrm{~h}$.

We next applied these conditions in the synthesis of peptides (Scheme 2). Again, high yields are reported in the coupling of protected amino acids, with a broad scope of functionality demonstrated (9 examples, 63-100\%). In addition to amino acids whose side chains bore alkyl and aryl substituents (e.g., $\mathbf{6 a}$ and $\mathbf{6 c}$ ), we found those containing protected and unprotected heteroaromatic residues could also be coupled in high yields (e.g. 6e and 6i). However, with some 
examples (6b, 6d, and $\mathbf{6 h}$ ) we found it necessary to increase the equivalents of HATU to improve the yield.

These conditions could also be applied to the gram-scale synthesis of $\mathbf{6 c}$. Following a series of aqueous washes and trituration with cold diethyl ether to ensure complete removal of Cyrene (See ESI for full work-up procedure), analytically pure product could be isolated in quantitative yield.

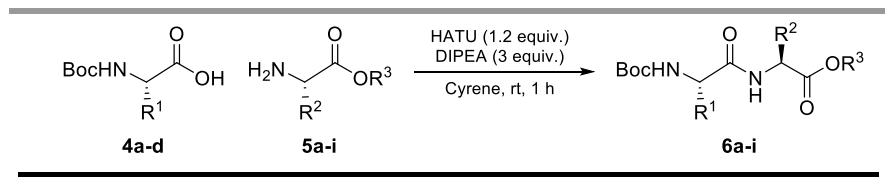

$$
\text { (6), } 77 \%^{\mathrm{a}}
$$<smiles>CCCCNC(=O)OCc1ccccc1</smiles>

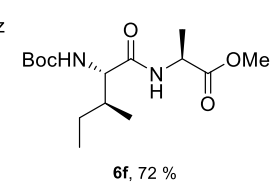<smiles>COC(=O)[C@H](Cc1ccc(O)cc1)NC(=O)[C@H](C)NC(=O)OCc1ccccc1</smiles>

$6 \mathbf{6}, 70 \%$
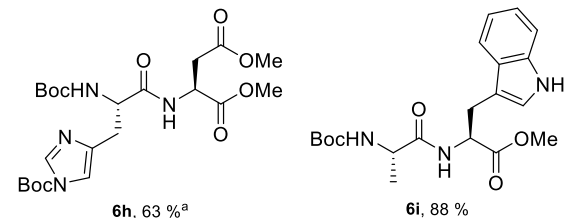

Scheme 2 HATU mediated amide bond formation: Scope of the coupling of amino acids. Isolated yields. Free acid ( 1 equiv., $0.25 \mathrm{mmol}$ ), free amine (1.1 equiv., 0.275 mmol), HATU (1.2 equiv., $0.3 \mathrm{mmol}$ ), DIPEA (3 equiv., $0.75 \mathrm{mmol}$ ), Cyrene $(1.25 \mathrm{~mL}, 0.2$ $\mathrm{M}), \mathrm{rt}, 1 \mathrm{~h} .{ }^{\mathrm{a}} 2.5$ equiv HATU.

\section{Conclusions}

In summary, we have evaluated the utility of Cyrene in HATU mediated amide bond formation as a direct alternative to conventional solvents (DMF, NMP). The conditions developed demonstrate broad generality and functional group tolerance and could be applied to the synthesis of both small molecules and peptides.

\section{Conflict of Interest}

Cyrene $^{\circledR}$ is sold $(£ 83 / 100 \mathrm{~mL}$ ) by Sigma-Aldrich (now Merck KGaA).

\section{Acknowledgements}

We thank the University of Strathclyde for a PhD studentship (KLW), Merck for financial and material support, Circa for provision of Cyrene, and the EPSRC UK National Mass Spectrometry Facility at Swansea University for analyses.

\section{Notes and references}

1 A. Greenberg, C. M. Breneman and J. F. Liebman, The Amide Linkage: Selected Structural Aspects in Chemistry, Biochemistry, and Material Science, Wiley, New York, 2000.

2 N. Sewald and H.-D. Jakubke, Peptides: Chemistry and Biology, Wiley-VCH Verlag GmbH, Weinheim, 2002.

3 D. G. Brown and J. Boström, J. Med. Chem., 2016, 59, 44434458.

4 S. D. Roughley and A. M. Jordan, J. Med. Chem., 2011, 54 3451-3479.

5 T. W. J. Cooper, I. B. Campbell, S. J. F. Macdonald, Angew. Chem. Int. Ed., 2010, 49, 8082-8091.

6 A. Henninot, J. C. Collins and J. M. Nuss, J. Med. Chem. 2017, DOI: 10.1021/acs.jmedchem.7b00318.

7 L. A. Carpino, J. Am. Chem. Soc., 1993, 115, 4397-4398.

8 A. El-Faham, R. Subirós-Funosas, R. Prohens, F. Albericio, Chem. Eur. J. 2009, 15, 9404-9416.

9 Candidate List of substances of very high concern for Authorisation - ECHA, https://echa.europa.eu/candidatelist-table, (accessed September 2017).

10 eChemPortal - Home, http://www.echemportal.org/echemportal/substancesearc $\mathrm{h} /$ page.action?pagelD $=0$, (accessed September 2017).

11 D. J. C. Constable, P. J. Dunn, J. D. Hayler, G. R. Humphrey, J. L. Leazer, R. J. Linderman, K. Lorenz, J. Manley, B. A. Pearlman, A. Wells, A. Zaks and T. Y. Zhang, Green Chem., 2007, 9, 411-420.

12 M. Tobiszewski, J. Namieśnik and F. Pena-Pereira, Green Chem., 2017, 19, 1034-1042.

13 C. M. Alder, J. D. Hayler, R. K. Henderson, A. M. Redman, L. Shukla, L. E. Shuster and H. F. Sneddon, Green Chem., 2016, 18, 3879-3890.

14 F. P. Byrne, S. Jin, G. Paggiola, T. H. M. Petchey, J. H. Clark, T. J. Farmer, A. J. Hunt, C. R. McElroy and J. Sherwood, Sustain. Chem. Process., 2016, 4:7.

15 L. J. Diorazio, D. R. J. Hose and N. K. Adlington, Org. Process Res. Dev., 2016, 20, 760-773.

16 D. Prat, A. Wells, J. Hayler, H. Sneddon, C. R. McElroy, S. Abou-Shehada and P. J. Dunn, Green Chem., 2015, 18, 288296.

17 K. Skowerski, J. Białecki, A. Tracz and T. K. Olszewski, Green Chem., 2014, 16, 1125-1130.

18 C. P. Ashcroft, P. J. Dunn, J. D. Hayler and A. S. Wells, Org. Process Res. Dev., 2015, 19, 740-747.

19 D. S. MacMillan, J. Murray, H. F. Sneddon, C. Jamieson and A. J. B. Watson, Green Chem., 2013, 15, 596-600.

20 S. Lawrenson, M. North, F. Peigneguy and A. Routledge, Green Chem., 2017, 19, 952-962.

21 A. Kumar, Y. E. Jad, A. El-Faham, B. G. de la Torre and F. Albericio, Tetrahedron Lett., 2017, 58, 2986-2988.

22 Y. E. Jad, T. Govender, H. G. Kruger, A. El-Faham, B. G. de la Torre and F. Albericio, Org. Process Res. Dev., 2017, 21, 365-369.

23 Y. E. Jad, G. A. Acosta, T. Govender, H. G. Kruger, A. ElFaham, B. G. de la Torre and F. Albericio, ACS Sustain. Chem. Eng., 2016, 4, 6809-6814.

24 Y. E. Jad, G. A. Acosta, S. N. Khattab, B. G. de la Torre, T. Govender, H. G. Kruger, A. El-Faham and F. Albericio, Amino Acids, 2016, 48, 419-426.

25 C. M. Gabriel, M. Keener, F. Gallou and B. H. Lipshutz, Org. Lett., 2015, 17, 3968-3971.

26 J. C. Philp, R. J. Ritchie and J. E. M. Allan, Trends Biotechnol., 2013, 31, 219-222.

27 I. T. Horváth, Green Chem., 2008, 10, 1024-1028.

28 S. K. Spear, S. T. Griffin, K. S. Granger, J. G. Huddleston and R. D. Rogers, Green Chem., 2007, 9, 1008-1015.

29 Y. Gu and F. Jérôme, Green Chem., 2010, 12, 1127-1138.

30 V. Pace, P. Hoyos, L. Castoldi, P. Dominguez de Maria and A. R. Alecantara, ChemSusChem, 2012, 5, 1369-1379. 
31 L. Lomba, B. Giner, I. Bandrés, C. Lafuente and R. Pino, Green Chem., 2011, 13, 2062-2070.

32 C. S. M. Pereira, V. M. T. M. Silva and A. E. Rodrigues, Green Chem., 2011, 13, 2658-2671.

33 D. M. Alonso, S. G. Wettstein and J. A. Dumesic, Green Chem., 2013, 15, 584-595.

34 F. Byrne, B. Forier, G. Bossaert, C. Hoebers, T. J. Farmer, J. H. Clark and A. J. Hunt, Green Chem., 2017, 19, 3671-3678.

35 S. Jin, F. Byrne, C. R. McElroy, J. Sherwood, J. H. Clark and A. J. Hunt, Faraday Discuss., 2017, 202, 157-173

36 S. H. Krishna, D. J. McClelland, Q. A. Rashke, J. A. Dumesic and G. W. Huber, Green Chem., 2017, 19, 1278-1285.

37 F. Cao, T. J. Schwartz, D. J. McClelland, S. H. Krishna, J. A. Dumesic and G. W. Huber, Energy Environ. Sci., 2015, 8, 1808-1815.

38 K. Koseki, T. Ebata, H. Kawakami, H. Matsushita, K. Itoh, Y. Naoi, Method of producing (S)-4-hydroxymethyl- - -lactone. U.S. Patent 5112994, May 12, 1992.

39 J. Sherwood, M. De Bruyn, A. Constantinou, L. Moity, C. R. Mcelroy, T. J. Farmer, T. Duncan, W. Raverty, A. J. Hunt and J. H. Clark, Chem. Commun., 2014, 50, 9650-9652.

40 REACH dossier for Cyrene https://echa.europa.eu/registration-dossier/-/registereddossier/16252 (accessed September 2017).

41 H. J. Salavagione, J. Sherwood, M. De Bruyn, V. L. Budarin, G. J. Ellis, J. H. Clark and P. S. Shuttleworth, Green Chem., 2017, 19, 2550-2560.

42 J. Zhang, G. B. White, M. D. Ryan, A. J. Hunt and M. J. Katz, ACS Sustain. Chem. Eng., 2016, 4, 7186-7192.

43 L. Mistry, K. Mapesa, T. W. Bousfield and J. E. Camp, Green Chem., 2017, 19, 2123-2128.

44 K. L. Wilson, A. R. Kennedy, J. Murray, B. Greatrex, C. Jamieson and A. J. B. Watson, Beilstein J. Org. Chem., 2016, 12, 2005-2011.

45 K. L. Wilson, J. Murray, C. Jamieson and A. J. B. Watson, Synlett, 2017, DOI: 10.1055/s-0036-1589143.

46 K. L. Wilson, J. Murray, H. F. Sneddon, K. M. P. Wheelhouse and A. J. B. Watson, Chem, 2017, 3, 365-368.

47 F. I. McGonagle, D. S. MacMillan, J. Murray, H. F. Sneddon, C. Jamieson and A. J. B. Watson, Green Chem., 2013, 15, 1159-1165.

48 D. S. MacMillan, J. Murray, H. F. Sneddon, C. Jamieson and A. J. B. Watson, Green Chem., 2012, 14, 3016-3019.

49 H. E. Eastman, C. Jamieson and A. J. B. Watson, Aldrichimica Acta., 2015, 48, 51-55. 